\title{
Raf induces TGF $\beta$ production while blocking its apoptotic but not invasive responses: a mechanism leading to increased malignancy in epithelial cells
}

\author{
Kerstin Lehmann, ${ }^{1}$ Elzbieta Janda, ${ }^{3}$ Christophe E. Pierreux, ${ }^{2}$ Marjatta Rytömaa, ${ }^{1}$ Almut Schulze, ${ }^{1}$ \\ Martin McMahon, ${ }^{4}$ Caroline S. Hill, ${ }^{2}$ Hartmut Beug, ${ }^{3}$ and Julian Downward ${ }^{1,5}$ \\ ${ }^{1}$ Signal Transduction and ${ }^{2}$ Developmental Signaling Laboratories, Imperial Cancer Research Fund, London WC2A 3PX, UK; \\ ${ }^{3}$ Institute of Molecular Pathology, A-1030 Vienna, Austria; ${ }^{4}$ Cancer Research Institute, UCSF/Mt. Zion Cancer Center, \\ San Francisco, California 94115-0128, USA
}

c-Raf-1 is a major effector of Ras proteins, responsible for activation of the ERK MAP kinase pathway and a critical regulator of both normal growth and oncogenic transformation. Using an inducible form of Raf in MDCK cells, we have shown that sustained activation of Raf alone is able to induce the transition from an epithelial to a mesenchymal phenotype. Raf promoted invasive growth in collagen gels, a characteristic of malignant cells; this was dependent on the operation of an autocrine loop involving TGFß, whose secretion was induced by Raf. TGF $\beta$ induced growth inhibition and apoptosis in normal MDCK cells: Activation of Raf led to inhibition of the ability of TGF $\beta$ to induce apoptosis but not growth retardation. ERK has been reported previously to inhibit TGFß signaling via phosphorylation of the linker region of Smads, which prevents their translocation to the nucleus. However, we found no evidence in this system that ERK can significantly influence the function of Smad2, Smad3, and Smad4 at the level of nuclear translocation, DNA binding, or transcriptional activation. Instead, strong activation of Raf caused a broad protection of these cells from various apoptotic stimuli, allowing them to respond to TGF $\beta$ with increased invasiveness while avoiding cell death. The Raf-MAP kinase pathway thus synergizes with TGF $\beta$ in promoting malignancy but does not directly impair TGF $\beta$-induced Smad signaling.

[Key Words: Ras; Raf; TGFß; SMAD; apoptosis]

Received May 23, 2000; revised version accepted August 8, 2000.

Activating mutations in the ras oncogenes occur in a high proportion of human cancers. Ras proteins act through a number of effectors to promote cell transformation, including the serine/threonine kinase Raf, which activates the ERK MAP kinase pathway, and the lipid kinase phosphoinositide 3-OH kinase (PI 3-kinase), which activates the serine/threonine kinase Akt and the small GTPase Rac (Downward 1998). Many carcinomas with activated ras oncogenes have undergone epithelial to mesenchymal transition (EMT), in which the epithelial phenotype, characterized by strong cell-cell junctions and polarity across the epithelial cell layer, is lost and a mesenchymal phenotype is acquired, characterized by weaker cell-cell interactions and increased motility (Schoenenberger et al. 1991; Birchmeier et al. 1993; Hay 1995). While the exact mechanisms by which Ras promotes EMT are not fully understood, it is likely to be important in the behavior of a number of tumor types, in

\footnotetext{
${ }^{5}$ Corresponding author.

E-MAIL downward@icrf.icnet.uk; FAX 44-20-7269-3094.

Article and publication are at www.genesdev.org/cgi/doi/10.1101/ gad. 181700 .
}

particular in the establishment of invasiveness and metastasis.

Mouse mammary epithelial cells expressing activated Ras (EpRas) respond to TGF $\beta$ by undergoing EMT and then continue to maintain the mesenchymal phenotype by producing TGF $\beta$ in an autocrine manner (Oft et al. 1996). In addition, several other lines of evidence suggest that TGF $\beta$ can act to promote malignant transformation of cells: The factor was originally identified because of its ability to promote transformation of fibroblasts in cooperation with TGF $\alpha$ (Roberts et al. 1981). TGF $\beta$ is produced by many advanced human tumors and has been reported to promote progression from squamous cell to spindle cell carcinoma in a mouse model of skin carcinogenesis (for review, see Akhurst and Balmain 1999). Its importance for tumor maintenance is also suggested by the fact that the second copy of the TGF 1 gene is not lost during chemical carcinogenesis in TGF 1 heterozygous mice. As TGF $\beta$ can promote angiogenesis, wound healing, and immunosuppression, at least some of its positive effects on tumor progression may be through action on cells other than those of the tumor itself. 
In apparent contradiction to the body of data implicating TGF $\beta$ in cancer progression, it is also a welldocumented inhibitor of cell growth and inducer of cell death. TGF $\beta$ inhibits progression through the cell cycle via its ability to disregulate the Cdk inhibitors $\mathrm{p} 21^{\mathrm{CIP} 1}, \mathrm{p} 27^{\mathrm{KIP} 1}$, and $\mathrm{p} 15^{\mathrm{INK} 4 \mathrm{~B}}$ and is able to induce caspase-mediated apoptosis (Oberhammer et al. 1992; Hannon and Beach 1994; Reynisdottir et al. 1995). Most tumors are resistant to the inhibitory effects of TGF $\beta$, which in a subset of tumor types has been shown to be caused by loss of TGF $\beta$ receptors or the downstream signaling protein Smad4/DPC4 (for review, see Massague 1998). This suggests that general loss of responsiveness to TGF $\beta$ may be important for epithelial cells to form tumors, with the positive effects of TGF $\beta$ on tumorigenesis possibly being due entirely to its actions on surrounding normal tissue interacting with the tumor.

Recently, it has been reported that the ERK MAP kinase, acting downstream of Ras, phosphorylates Smad2 and Smad3 in the linker region connecting the $\mathrm{MH} 1$ and MH2 domains (Kretzschmar et al. 1999). This prevents their translocation to the nucleus in response to TGF $\beta$, causing a general inhibition of TGF $\beta$ responses in epithelial cells. This model leaves little room for cell-autonomous effects of TGF $\beta$ on the promotion of tumorigenesis, such as have been reported recently; for example, expression of a dominant negative TGF $\beta$ receptor inhibits metastasis formation in mice by tumor cells that have undergone EMT (Oft et al. 1998; Yin et al. 1999).

These apparent contradictions between the roles of TGF $\beta$ as a tumor suppressor and as a tumor promoter prompted us to look in more detail at the interactions between the Ras-MAP kinase pathway and TGF $\beta$ signaling. In particular, we have addressed the issue of whether activation of Raf causes a global inhibition of TGF $\beta$ signaling, at least through Smads, or whether the effects are more selective, acting only on the tumor-suppressive aspects of the TGF $\beta$ response. We find that sustained Raf activation is able to induce EMT in MDCK cells, leading to the establishment of an autocrine TGF $\beta$ loop that promotes invasive behavior of the cells in collagen gels in vitro. The ability of TGF $\beta$ to cause invasive growth is not inhibited by Raf, but the apoptotic effects of TGF $\beta$ are blocked. This inhibition of apoptosis is not restricted to TGF $\beta$ but is common to several death stimuli. Raf activation does not impair TGF $\beta$-induced Smad signaling in this system. We propose that activation of the Raf-MAP kinase pathway does not specifically inhibit TGF $\beta$ signaling but, rather, allows cells to display only the promalignant aspects of the TGF $\beta$ response, such as invasiveness, while broadly blocking apoptotic responses.

\section{Results}

Activation of Raf-ER leads to rapid phosphorylation of $\mathrm{p} 42 \mathrm{MAPK}$ in MDCK cells

To investigate the role of Raf kinase in the regulation of epithelial cell morphology and in mediating antiapoptotic effects, we generated epithelial MDCK cells stably expressing a 4-hydroxytamoxifen (4HT) inducible EGFP$\Delta$ Raf-1-hbER(DD) fusion protein (Woods et al. 1997). This fusion protein (abbreviated Raf-ER) consists of the catalytic domain of Raf-1 lacking the Ras binding site $(\Delta$ Raf-1), with the two tyrosine phosphorylation sites Y340 and Y341 substituted by aspartic acid residues (DD), potentiating its kinase activity (Bosch et al. 1997). MDCK Raf-ER cells were tested for activation of the MAPK pathway. Cells were starved and treated with 4HT for different times (Fig. 1A), and lysates were assayed for phosphorylation of p42MAPK and expression of the Raf-ER fusion protein by Western blotting. Induction of the Raf-ER fusion protein resulted in a rapid and sustained phosphorylation of p42MAPK, which was already detectable 15 min after stimulation and increased with time. In contrast, stimulation with EGF or HGF/SF led to a more rapid but only transient phosphorylation of MAPK (data not shown). In contrast, control cells carrying empty vector (mock) showed no phosphorylation of MAPK in response to $4 \mathrm{HT}$ treatment (Fig. 1B). As expected, pretreatment with the MEK inhibitor PD98059 completely abolished MAPK phosphorylation (Fig. 1B), indicating that the inducible Raf-ER system mirrors the growth factor-induced activation of the MAPK pathway.

\section{Induction of morphological changes following Raf activation in MDCK cells}

Having established the inducible Raf-ER fusion protein in MDCK cells, we examined morphological effects caused by Raf activation (Fig. 1C-F). As HGF/SF is a physiological activator of the Raf-MAPK pathway that causes cell scattering, we compared HGF/SF-induced morphological effects to Raf-ER effects. MDCK Raf-ER cells were treated with $4 \mathrm{HT}$ or HGF/SF and phase-contrast pictures were taken before and after Raf activation. While MDCK Raf-ER cells in the absence of 4HT grow in compact islands like wild-type cells (Fig. 1C), activation of Raf-ER with $4 \mathrm{HT}$ for $24 \mathrm{~h}$ leads to disruption of intercellular contacts and increased cell migration (Fig. 1E), similar to the scattering effect, as observed with HGF-SF (Fig. 1D; Stoker et al. 1987; Gherardi et al. 1989). Interestingly, the onset of both HGF/SF- and RafER-mediated morphological effects occurred with similar kinetics as observed by time-lapse video microscopy (data not shown). Treatment with HGF/SF or 4HT led to disruption of cell-cell contacts by $8 \mathrm{~h}$, and cell motility increased within $12 \mathrm{~h}$. Pretreatment of the cells with the MEK inhibitor PD98059 (30 $\mu \mathrm{M})$, the PI 3-kinase inhibitor LY294002 $(20 \mu \mathrm{M})$, or the protein synthesis inhibitor cycloheximide $(10 \mathrm{ng} / \mathrm{mL}$ ) completely blocked the Rafinduced scattering response (data not shown). These findings suggest that basal PI 3-kinase activity as well as protein synthesis is required for cell scattering (Boyer et al. 1997; Khwaja et al. 1998). Whereas the HGF/SF mediated scattered phenotype is completely reverted after $3 \mathrm{~d}$ in the presence of ligand (data not shown), sus- 
A

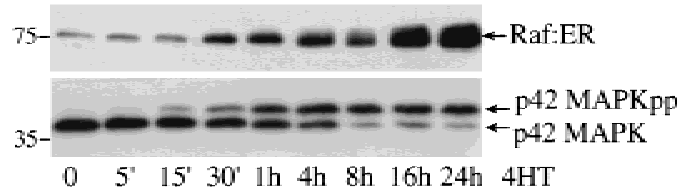

B
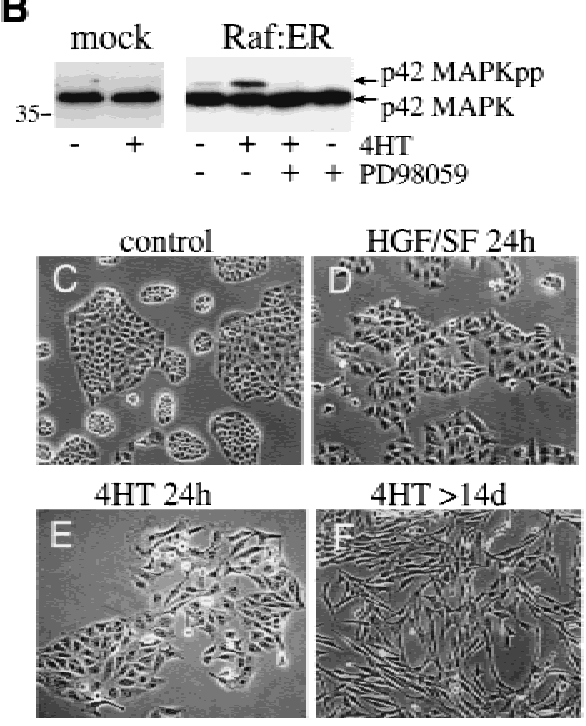

$4 \mathrm{HT}>14 \mathrm{~d}$

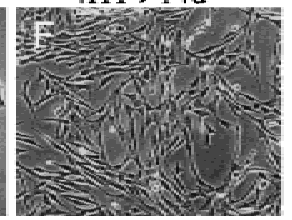

Figure 1. Activation of Raf-ER leads to rapid phosphorylation of p42MAPK and induction of morphological changes in MDCK cells. (A) MDCK cells expressing Raf-ER were serum starved in DMEM +0.5\% BSA for $24 \mathrm{~h}$ before treatment with $100 \mathrm{nM}$ 4-hydroxy-tamoxifen $(4 \mathrm{HT})$ for the indicated times. Cytoplasmic lysates were assayed for the expression of Raf-ER fusion protein using an antiestrogen receptor antibody and the mobility shift of p42MAPK to the phosphorylated form. (B) Control MDCK cells carrying empty vector (mock) and MDCK Raf-ER cells were serum starved for $24 \mathrm{~h}$ and either untreated or treated with $100 \mathrm{nM} 4 \mathrm{HT}$ for $1 \mathrm{~h}$. The MEK inhibitor PD98059 (30 $\mu \mathrm{M})$ was applied 20 min before $4 \mathrm{HT}$ treatment, and p42MAPK activity was assayed by immunoblotting.(C) MDCK Raf-ER cells were either untreated or $(E)$ treated with $100 \mathrm{nM} 4 \mathrm{HT}$ for $24 \mathrm{~h}$ or $(F)$ $>14 \mathrm{~d}$ or $(D)$ with $10 \mathrm{ng} / \mathrm{ml} \mathrm{HGF/SF}$ for $24 \mathrm{~h}$ and examined by phase contrast microscopy.

tained Raf activation leads to further changes in cell morphology (Fig. 1F). Cells became elongated and spindle shaped, indicating a conversion from the epithelial to a mesenchymal phenotype, which was stably maintained after $14 \mathrm{~d}$ of $4 \mathrm{HT}$ treatment. These results and the ability of the converted cells to grow in soft agar (data not shown) indicate that sustained Raf-ER activation in MDCK cells is sufficient to mediate cell transformation.

\section{Activation of Raf-ER leads to repression of epithelial and induction of mesenchymal marker proteins}

Conversion from an epithelial to a mesenchymal phenotype is characterized by decreased organization of inter- cellular junctions, loss of epithelial characteristics, and gain of mesenchymal characteristics (Greenburg and Hay 1986; Boyer et al. 1989). To investigate Raf-ER-mediated changes in cell morphology, immunostaining of epithelial and mesenchymal marker proteins was performed (Fig. 2). Optical sections were obtained at 0.25$\mu \mathrm{m}$ intervals, and three-dimensional stacks of images were generated.

The immunostaining pattern showed that in unstimulated MDCK Raf-ER cells the adherens junction protein E-cadherin and the tight junction component ZO-1 are localized to intercellular junctions (Fig. 2a,e). Moreover in vertical sections (Fig. 2i), uninduced MDCK cells exhibited a polarized phenotype as demonstrated by localization of ZO-1 at the apical cell borders above the Ecadherin localization.

Within $4 \mathrm{~d}$ of $4 \mathrm{HT}$ treatment (Fig. 2b), ZO-1 was largely removed from the cell-cell junctions and diffusely expressed over the cell surface. This effect was even more pronounced after $6 \mathrm{~d}$ of $4 \mathrm{HT}$ treatment (Fig. 2c) and in MDCK Raf-ER cells that were transformed following sustained Raf activation (Fig. 2d). After 4HT addition for $4 \mathrm{~d}$, E-cadherin was present at the intercellular contacts (Fig. 2f), which were now much more loosely formed, as well as on the cell surface, as observed in the vertical section (Fig. 2j). In contrast, after sustained Raf activation the localization of E-cadherin became diffuse and much reduced (Fig. 2g,h). In the absence of $4 \mathrm{HT}$ (Fig. $2 \mathrm{k}$ ), the intermediate filament protein cytokeratin 18 forms a network of filaments inside the cell borders. After treatment with 4HT for $4 \mathrm{~d}$ (Fig. 21) or $6 \mathrm{~d}$ (Fig. 2m), only a few cytokeratin filaments across the cell body were visible, and levels were much reduced in the Raf transformed MDCK Raf-ER cells (Fig. 2n). Immunostaining for the mesenchymal marker protein vimentin, a cytoskeletal intermediate filament protein, shows low expression in the uninduced MDCK cells (Fig. 2o) but strong staining after $6 \mathrm{~d}$ of $4 \mathrm{HT}$ treatment (Fig. 2q) as well as in the Raf-transformed cells (Fig. 2r).

These results show that a strong and sustained Raf signal is sufficient to induce epithelial to mesenchymal transition (EMT), characterized by loss of apical-basal polarity, and epithelial marker proteins and expression of mesenchymal marker proteins (for review, see Birchmeier et al. 1995; Hay 1995).

\section{Activation of Raf in MDCK cells induces secretion of TGF $\beta$}

It has been shown that the process of EMT is accompanied by secretion of TGF $\beta 1$, which is required to maintain the transformed phenotype (Oft et al. 1996). MDCK Raf-ER cells were therefore treated at different times with 4HT and cell culture supernatants analyzed for the presence of TGF $\beta 1$ by ELISA (Fig. 3A). Treatment with $4 \mathrm{HT}$ for $48 \mathrm{~h}$ led to a threefold up-regulation of TGF $\beta$ protein in the medium. An eightfold increase was seen after sustained Raf activation for $>14 \mathrm{~d}$, when MDCK cells have undergone EMT. Secretion of TGF $\beta$ in response to Raf-ER activation was also demonstrated by 


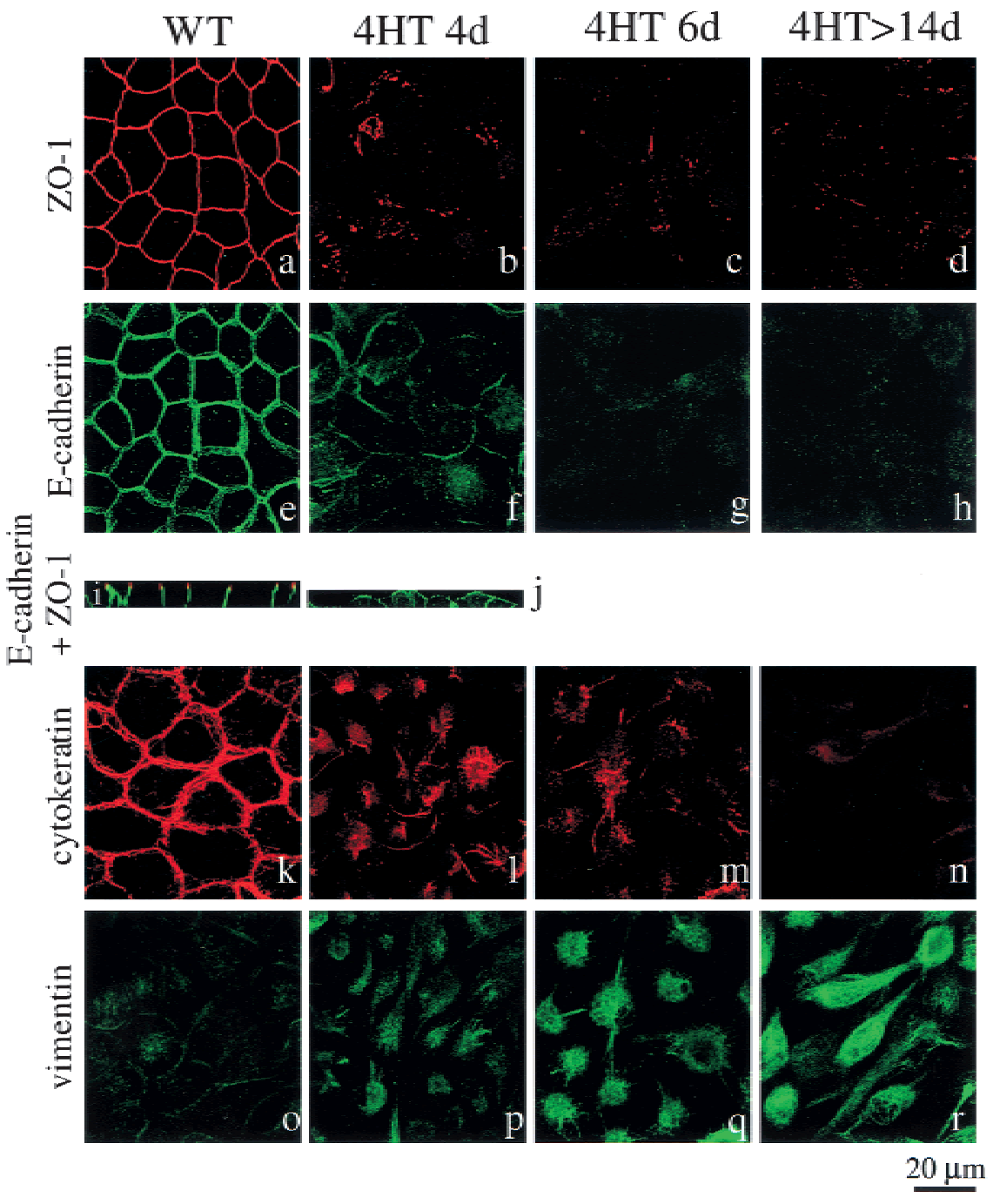

Figure 2. Activation of Raf-ER leads to repression of epithelial marker proteins and induction of expression of a mesenchymal marker protein. MDCK Raf-ER cells either untreated $(a, e, i, k, o)$ or treated with $100 \mathrm{nM} 4 \mathrm{HT}$ for $4 \mathrm{~d}(b, f, j, l, p), 6 \mathrm{~d}(c, g, m, q)$ or after sustained Raf activation $(>14 \mathrm{~d} ; d, h, n, r)$ were immunostained with antibodies recognizing E-cadherin, ZO-1, cytokeratin, and vimentin and examined by confocal laser scanning microscopy. Confocal images show three-dimensional stacks of horizontal sections $(a-h, k-r)$ or of vertical sections $(i, j)$.

immunoblotting of concentrated cell culture supernatants (Fig 3B). As it has been shown that the biologically active form of TGF $\beta$ is released from its cell surfacebound latent proform (LTGF $\beta 1$ ) by serine protease urokinase-type plasminogen activator (uPA) induced plasmin activation (Lyons et al. 1990; Godar et al. 1999), we asked whether Raf-ER activation leads to uPA secretion in MDCK cells. The onset of UPA secretion was already detectable after $8 \mathrm{~h}$ of treatment with $4 \mathrm{HT}$ and increased with time in a manner similar to TGF $\beta$ secretion. Activation of uPA increases the expression of matrix-metalloproteases (MMP) and promotes the degradation of extracellular matrix components, a prerequisite for invasive growth of tumor cells (Rosenthal et al. 1998).

We next assayed the biological activity of the secreted TGF $\beta$ induced by Raf using the electrophoretic mobility shift assay (EMSA) on a ${ }^{32} \mathrm{P}$-labeled c-jun probe shown to bind TGF $\beta$ induced activated Smad3 in complex with Smad4 (Wong et al. 1999). Concentrated cell culture supernatant from Raf-transformed MDCK Raf-ER cells (cmRafT) was able to induce TGF $\beta$ signaling in control MDCK cells (mock), detected by a complex that bound the c-jun probe (Fig 3C, lanes 2, 4). The same complex is induced by exogenously added TGF 3 (Fig 3C, lanes 1,2). To confirm that this complex was formed by TGF $\beta$-activated Smad3 and Smad4, we quantitatively supershifted the TGF $\beta$-induced complex in the presence of an anti-Smad4 antibody or an anti-Smad3 antibody (Fig. 3C, lanes 7,9$)$. Addition of the peptide used to raise the antiSmad3 antibody prevented the supershift (Fig. 3C, lane 8). The commercial anti-Smad2 antibody (Transduction Laboratories) that cross-reacts with Smad3 (data not shown) efficiently supershifted the Smad3/4 complex (Fig. 3C, lane 10). However, a more specific anti-Smad2 
Figure 3. Activation of Raf in MDCK cells induces secretion of TGF $\beta$. (A) MDCK Raf-ER cells, control MDCK cells, and MDCK Raf-ER cells transformed by long-term culture in 4HT (Raf T) were cultivated in the presence or absence of $100 \mathrm{nM} 4 \mathrm{HT}$ in DMEM $+2 \%$ FCS for $24 \mathrm{~h}$. Cells were cultured in DMEM $+0.5 \%$ BSA for a further $24 \mathrm{~h}$ before collecting the supernatants. Cell culture supernatants were examined for TGF $\beta 1$ levels by ELISA. The values shown were normalized for cell number. (B) MDCK Raf-ER cells, control MDCK cells, and Raf-transformed MDCK RafER cells (RafT) were cultured in DMEM $+2 \%$ FCS and stimulated with $100 \mathrm{nM}$ 4HT for the indicated times. The cell culture supernatant was concentrated by ultrafiltration and equal aliquots were analyzed by $12 \%$ SDS-PAGE under nonreducing conditions and immuno-

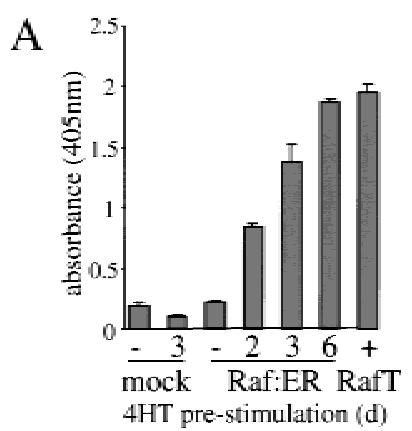

$\mathrm{B}$

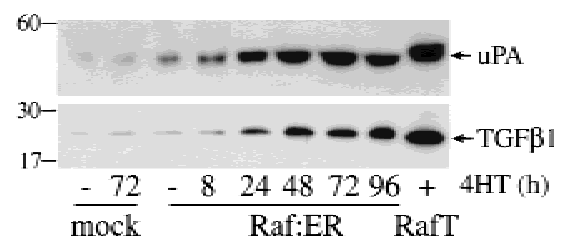

C

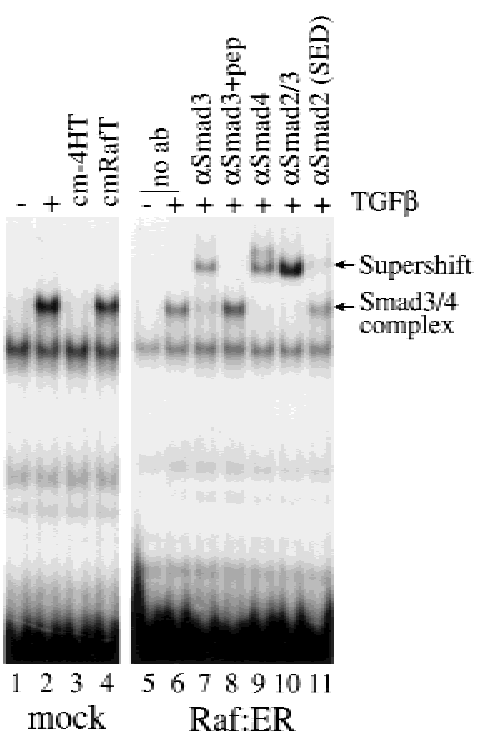

blotted for TGF $\beta$ and Urokinase-type Plasminogen Activator (uPA). (C) MDCK control cells were either untreated or treated for $1 \mathrm{~h}$ with $2 \mathrm{ng} / \mathrm{mL}$ TGF $\beta$, with conditioned medium of $4 \mathrm{HT}$ untreated MDCK Raf-ER cells $(\mathrm{cm}-4 \mathrm{HT}$ ) or with conditioned medium of MDCK Raf-ER cells transformed by long-term exposure to 4HT (cmRafT). Nuclear extracts were assayed for the binding of activated Smad3/4 complexes to a ${ }^{32}$ P-labeled c-jun oligonucleotide probe by EMSA (lanes 1-4). Untreated MDCK Raf-ER cells were stimulated with $2 \mathrm{ng} / \mathrm{mL}$ TGF $\beta$ for $1 \mathrm{~h}$, and nuclear extracts were assayed in supershifts for the presence of Smads in complexes bound to the c-jun probe with the following antibodies: anti-Smad3, anti-Smad4, anti-Smad2, cross-reacting with Smad3 (Transduction Laboratories), and anti-Smad2 (SED). Peptide competition was performed with anti-Smad3 (Smad3 +pep).

antibody (SED) did not modify the mobility of the complex (Fig. 3C, lane 11; Nakao et al. 1997).

Taken together these results indicate that Raf induces secretion of uPA and biologically active TGF $\beta$, which are components known to play important roles in invasiveness and cell transformation.

Activation of Raf in MDCK cells leads to establishment of an invasive phenotype in collagen gels dependent on autocrine TGF $\beta$ stimulation

Having shown that TGF $\beta$ is secreted during Raf-induced EMT, we set out to analyze its role in this process. MDCK Raf-ER cells were cultured in collagen gels in the presence or absence of 4HT. Whereas wild-type MDCK cells (Fig. 4a) and untreated MDCK Raf-ER cells (Fig. 4b) grew in typical lumen-containing cysts (Khwaja et al. 1998), treatment with 4HT led to elongated, branched structures growing in an invasive manner (Fig. 4c). Moreover, the Raf-transformed MDCK Raf-ER cells led to formation of invasive growing cord-like structures (Fig. 4d). As TGF $\beta$ is known to inhibit growth and to induce apoptosis in epithelial cells grown in collagen (Oft et al. 1996) we examined the effects of TGF $\beta$ on wild-type and untreated MDCK Raf-ER cells that had been cultivated in collagen gels for $12 \mathrm{~d}$. When cells were grown in the presence of TGF $\beta$ for $6 \mathrm{~d}$, the cystic structures were degraded and dissociated into small fragments (Fig. 4e,f), probably reflecting apoptotic effects of TGF $\beta$. In contrast, Raf-expressing cells (Fig. 4g,h) maintained their in-
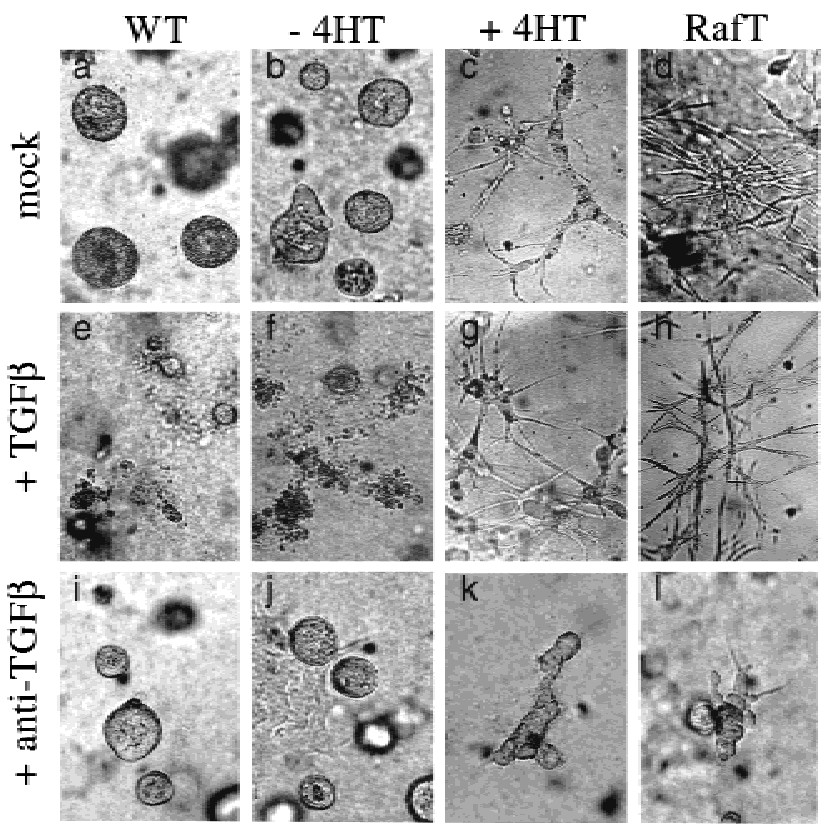

Figure 4. Activation of Raf in MDCK cells leads to formation of an invasive phenotype in collagen gels dependent on autocrine TGF $\beta$ effects. Wild-type MDCK cells (WT; $a, e, i)$, MDCK Raf-ER cells either untreated $(b, f, j)$ or treated $(c, g, k)$ with 200 $\mathrm{nM} 4 \mathrm{HT}$ for $6 \mathrm{~d}$ and MDCK Raf-ER cells transformed by longterm $4 \mathrm{HT}$ stimulation $(\mathrm{RafT} ; d, h, 1)$ were grown in type I collagen matrices in the absence $(a-d)$ or presence of $5 \mathrm{ng} / \mathrm{mL}$ TGF $\beta$ $(e-h)$ or neutralizing TGF $\beta$ antibodies $(i-1)$ for a further $6 \mathrm{~d}$ under serum-free conditions. Structures were photographed at $20 \times$ magnification. 
vasive phenotype in the presence of TGFß. To examine if blocking of TGF $\beta$ signaling would cause reversion of the invasive phenotype, we tested the ability of neutralizing TGF $\beta$ antibodies to inhibit this process. MDCK Raf-ER cells were treated with 4HT for $6 \mathrm{~d}$ before TGF $\beta$-neutralizing antibodies were added for a further $6 \mathrm{~d}$. This led to a reversion of the invasive structures into cysts, indicating that TGF $\beta$ secretion is required to sustain the invasive phenotype.

Together, these results indicate that activation of RafER induces invasive growth in collagen gels and that autocrine TGF $\beta$ function is required to maintain this Raf-induced phenotype.

\section{Short-term activation of Raf does not prevent} TGF $\beta$-induced cell cycle arrest

We have demonstrated that activation of Raf-ER overcomes TGF $\beta$ inhibitory effects of MDCK cells in collagen gels. In order to characterize whether Raf activation interferes with TGF $\beta$-mediated growth arrest, cell cycle distribution was examined (Fig. 5A). In MDCK Raf-ER cells pretreated with $4 \mathrm{HT}$, the exposure to TGF $\beta$ led to an increased percentage of cells in $\mathrm{G}_{1}(67 \%)$ and a reduced percentage of cells in $S$ phase $(9 \%)$, comparable to TGF $\beta$ effects in $4 \mathrm{HT}$ untreated cells $\left(\mathrm{G}_{1}: 63 \%\right.$; S: $\left.20 \%\right)$. In contrast, cells transformed by prolonged activation of Raf (RafT) were insensitive to TGF $\beta$-induced growth arrest. As it has been shown that TGF $\beta$ directly induces down-regulation of cyclin A in epithelial cells (Ralph et al. 1993), we also investigated the influence of TGF $\beta$ on cyclin A expression by Western blotting of total lysates (Fig. 5B). In proliferating cells cyclin A is up-regulated in late $G_{1}$ indicating cell cycle progression into $S$ phase. In asynchronously growing MDCK Raf-ER cells, cyclin A was highly expressed in the absence of TGF $\beta$, and pretreatment with $4 \mathrm{HT}$ for $24 \mathrm{~h}$ did not alter the expression level, whereas addition of TGF $\beta$ led to a dramatic decrease in cyclin A expression in both $4 \mathrm{HT}$-treated and untreated cells. Consistent with the data obtained above, the Raf transformed MDCK Raf-ER cells showed no changes in cyclin A expression, indicating that they were
A
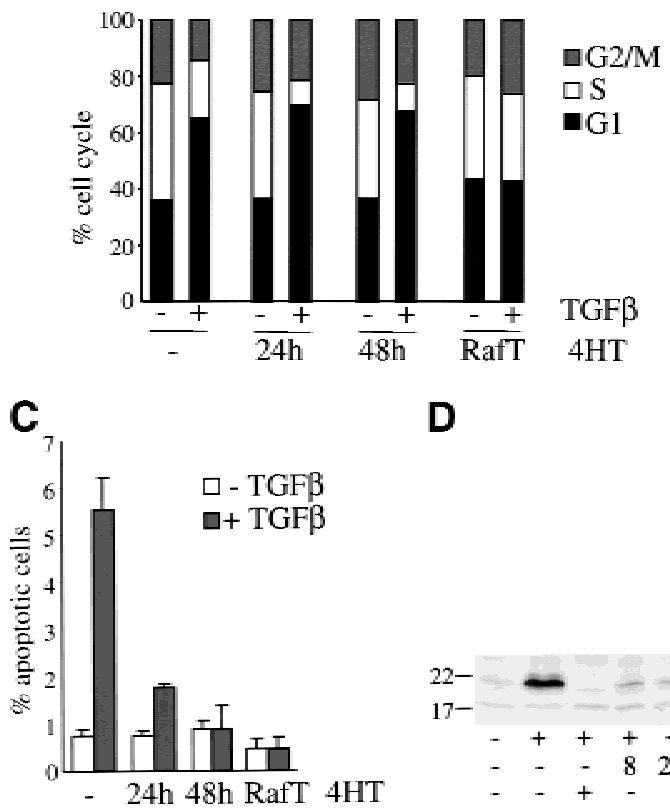

B

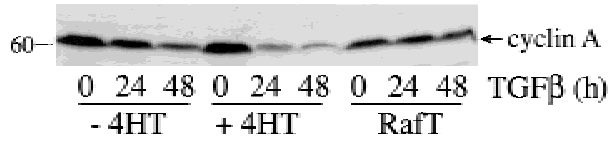

E
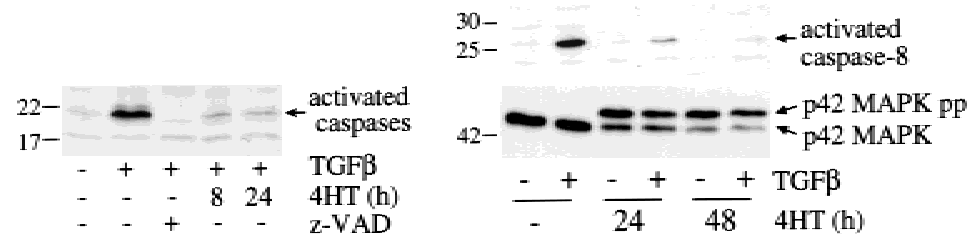

Figure 5. Short-term activation of Raf does not prevent TGF $\beta$-induced cell cycle arrest but blocks TGF $\beta$-induced apoptosis. $(A)$ MDCK Raf-ER cells either untreated or treated with $100 \mathrm{nM} 4 \mathrm{HT}$ for 24 or $48 \mathrm{~h}$ and MDCK Raf-ER cells transformed by long-term exposure to $4 \mathrm{HT}$ (RafT) were stimulated with TGF $(7.5 \mathrm{ng} / \mathrm{mL})$ for $24 \mathrm{~h}$. The medium was changed to DMEM $+2 \%$ FCS $24 \mathrm{~h}$ before TGF $\beta$ treatment. The cell cycle distribution was assayed by flow cytometry following propidium iodide staining. $(B)$ MDCK Raf-ER cells either untreated or pretreated with $100 \mathrm{nM} 4 \mathrm{HT}$ and MDCK Raf-ER cells transformed by long-term treatment with 4HT (RafT) were stimulated with $7.5 \mathrm{ng} / \mathrm{mL}$ TGF $\beta$ for the indicated times. Cells were cultured in DMEM $+2 \%$ FCS for 24 h before TGF $\beta$ stimulation and assayed for cyclin A expression by Western blotting. (C) MDCK Raf-ER cells transformed by long-term exposure to 4HT (RafT) and MDCK Raf-ER cells either untreated or pretreated with $100 \mathrm{nM} 4 \mathrm{HT}$ for the indicated periods of time were stimulated with $7.5 \mathrm{ng} / \mathrm{mL}$ TGFß for $24 \mathrm{~h}$. The percentage of apoptotic cells was determined by Hoechst staining. Data shown are the means \pm standard deviations of three independent experiments performed in duplicate. $(D)$ Effect of activated Raf on TGF $\beta$-induced caspase activation. MDCK Raf-ER cells either untreated or pretreated with $100 \mathrm{nM} 4 \mathrm{HT}$ for $8 \mathrm{~h}$ or $24 \mathrm{~h}$ were stimulated with 7.5 $\mathrm{ng} / \mathrm{mL}$ TGF $\beta$ for $24 \mathrm{~h}$. To inhibit caspase activation cells were pretreated with $100 \mu \mathrm{M} z$-VAD for 20 min. Cytosolic lysates were incubated with ZEK(bio)D-aomk peptide for $5 \mathrm{~min}$ at $37^{\circ} \mathrm{C}$ and assayed by Western blotting. (E) Activation of caspase- 8 and p42MAPK was detected in MDCK Raf-ER cells either untreated or pretreated with $100 \mathrm{nM} 4 \mathrm{HT}$ for 24 or $48 \mathrm{~h}$. After stimulation with TGF (7.5 $\mathrm{ng} / \mathrm{mL}$ ) for $24 \mathrm{~h}$, total cell lysates were analyzed by Western blotting. 
no longer sensitive to growth-inhibitory signals mediated by TGF $\beta$.

Together, these findings suggest that TGF $\beta$-induced growth arrest is not perturbed by Raf activation over a period of a few days, whereas long-term Raf-transformed MDCK cells, which have already undergone EMT, show a loss in the antiproliferative response to TGF $\beta$.

\section{TGF $\beta$-induced apoptosis can be blocked by activation} of Raf

As it has been shown that TGF $\beta$ induces apoptosis via activation of the caspase cascade in a variety of cell types (Chen and Chang 1997), we explored both the role of TGF $\beta$ in triggering a pro-apoptotic signal and the influence of Raf on this process. Apoptosis in MDCK cells was scored following TGF $\beta$ treatment by determining the percentage of nuclei with condensed chromatin. TGF $\beta 1$ treatment resulted in a 7.5 -fold increase in the percentage of apoptotic cells (Fig. 5C), whereas pretreatment with $4 \mathrm{HT}$ for $48 \mathrm{~h}$ or long term (RafT) completely abolished TGF $\beta$-induced apoptosis. We next examined the activation of effector caspases in response to TGF $\beta$. Cytosolic lysates were affinity labeled with the Z-EK(bio)D-aomk peptide, which binds covalently to activated caspases (Martins et al. 1997). TGF $\beta$ stimulation led to strong caspase activation, which was prevented by pretreatment of the cells with the pan-caspase inhibitor $z$-VAD (Fig. 5D). Raf activation before the addition of TGF $\beta$ was also able to block caspase activation. Moreover, we investigated the activation of caspase- 8 in response to TGF $\beta$ (Fig. 5E, upper panel). It has been shown that on cellular death receptor stimulation, the initiator caspase- 8 becomes activated, facilitating cleavage and activation of various effector caspases (Muzio et al. 1996; for review, see Wolf and Green 1999). Caspase-8 can also be activated downstream of effector caspases as part of an amplification loop (Schulze-Osthoff et al. 1998). Immunoblot analysis showed that TGF $\beta$ treatment led to strong activation of caspase-8, which was abolished in MDCK Raf-ER cells pretreated with $4 \mathrm{HT}$. Taken together, these findings indicate that TGF $\beta$ provides a proapoptotic stimulus to MDCK cells by activating the caspase cascade. However, TGF $\beta$-induced caspase activation was completely blocked by short-term Raf activation, showing that the Raf-MAPK pathway rapidly antagonizes TGF $\beta$-mediated apoptosis.

\section{Activation of Raf does not affect signal transduction by Smads}

We have shown that the activation of Raf-ER in MDCK cells leads to secretion of TGF $\beta$, which is necessary to maintain a highly transformed state, and at the same time, activated Raf renders the cells insensitive to the pro-apoptotic effects of TGF $\beta$. So far, the mechanism by which activated Raf-ER inhibits TGF $\beta$-mediated apoptosis is not known. Therefore, we studied the impact of
Raf activation on TGF $\beta$-mediated Smad signaling. Recently, it has been shown by others (Kretzschmar et al. 1999) that activation of Ras or EGF signaling in mouse epithelial cells blocks the TGF $\beta$-induced translocation of the Smads into the nucleus and thus inhibits the TGF $\beta$-induced transcriptional response. It was therefore important to study in the MDCK Raf-ER cells whether activation of Raf interferes directly with the TGF $\beta-$ Smad pathway. We studied several aspects of TGF $\beta$ signaling, namely the translocation of Smads into the nucleus, the binding of Smads to DNA, and finally, the Smad-dependent transcriptional response to TGF $\beta$. MDCK Raf-ER cells, untreated or pretreated with $4 \mathrm{HT}$, and MDCK V12Ras cells were stimulated with TGF $\beta$, and nuclear extracts were immunoblotted with antibodies to detect Smad2, Smad3, and Smad4. Only very little Smad4 was detected in the nucleus in the absence of a TGF $\beta$ signal, whereas exposure to TGF $\beta$ led to high accumulation of Smad4 in the nucleus (Fig. 6A, top panel). The same result was obtained with the anti-Smad2/3 antibody (Fig. 6A, second panel), indicating that Smad2, Smad3, and Smad4 translocated to the nucleus in response to TGF $\beta$ stimulation, which was not impaired in MDCK Raf-ER cells pretreated with 4HT. MDCK cells constitutively expressing the activated form of Ras (MDCK V12Ras) also showed clear nuclear translocation of Smad2, Smad3, and Smad4 in response to TGFß. On Raf activation, the phosphorylated form of p42MAPK is readily detectable in the nucleus and is not affected by exposure to TGF $\beta$ (Fig. 6A, third panel). In addition, immunoblotting of the nuclear extracts showed no contamination with the cytosolic adaptor protein Grb2 (data not shown). From this experiment we conclude that activation of the Ras-Raf-MAPK pathway does not prevent TGFß-induced Smad translocation into the nucleus.

Next, the same nuclear extracts were used to examine the ability of the translocated Smads to bind DNA, a prerequisite for gene activation. Using the ${ }^{32} \mathrm{P}$-labeled c-jun probe as a readout for the $S m a d 3 / 4$ binding to DNA in the EMSA, we only observed a shifted protein-DNA complex in the nuclear extracts from cells treated with TGFß (Fig. 6B, lanes 2,4,6,8,10). Again, Raf or Ras activation did not prevent nuclear Smad3 and Smad4 binding to DNA. Dose-response analysis revealed no effect of Raf stimulation on Smad3 activation even at low concentrations of TGF $\beta$ (data not shown).

Finally, we studied whether activation of Raf-ER affects the transcriptional activity of the Smads in response to TGF $\beta$. It has been shown that activated Smad2 and Smad4 are recruited by transcription factors to regulatory regions of TGF $\beta$ target genes. For example, activated Smad2 and Smad4 can be recruited to the activin/ TGF $\beta$ responsive element (ARE) of the Mix. 2 promoter by the winged helix transcription factor Fast- 1 and then can stimulate transcription in a signal-dependent manner (Huang et al. 1995; Chen et al. 1996).

To assay the transcriptional activity of the Smads in the presence of activated Raf, we transiently transfected MDCK Raf-ER cells with a plasmid encoding the luciferase reporter gene driven by three copies of the ARE 
A

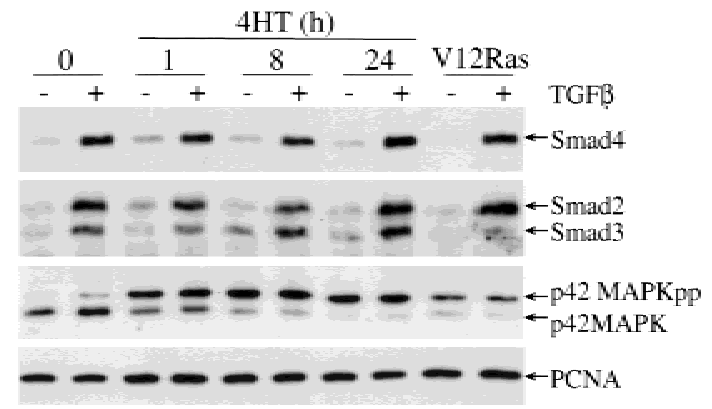

B
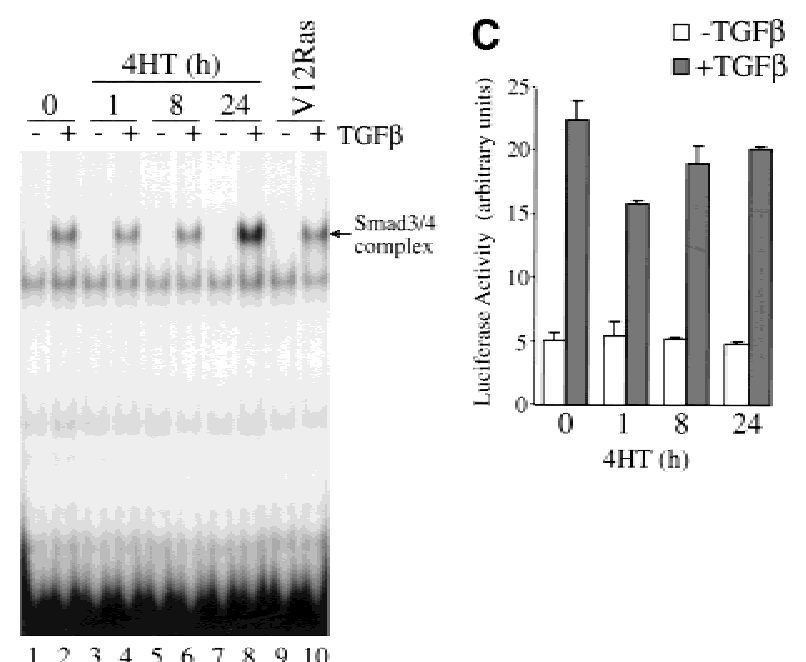

Figure 6. TGF $\beta$-induced nuclear translocation, DNA-binding, and transcriptional activity of $S \operatorname{mad} 3 / 4$ complexes is not affected by Raf activation. MDCK Raf-ER cells either untreated or pretreated with $100 \mathrm{nM} 4 \mathrm{HT}$ for the indicated time periods and V12Ras MDCK cells were stimulated with TGF $(2 \mathrm{ng} / \mathrm{mL})$ for 1 h. (A) Nuclear translocation of Smad4, Smad2, Smad3, and activation of p42MAPK were detected in nuclear extracts by Western blotting. Expression of PCNA, a nuclear protein was assayed to show equal loading of nuclear extracts. $(B)$ Activated $\mathrm{Smad} 3 / 4$ binding to a ${ }^{32} \mathrm{P}$ labeled c-jun probe was examined in nuclear extracts by EMSA. (C) MDCK Raf-ER cells were transiently transfected with ARE-Luc reporter, pEF-XFast1, and pEF-lacZ. After treatment with $100 \mathrm{nM} 4 \mathrm{HT}$ for the indicated periods of time, cells were stimulated with $2 \mathrm{ng} / \mathrm{mL}$ TGF $\beta$ for 6 $\mathrm{h}$ and activation of the ARE-Luc reporter was measured. Luciferase activity was normalized to the activity of the cotransfected $\beta$-galactosidase control plasmid. Data shown are the means \pm average deviations of duplicates from one out of three representative experiments.

(Fig. 6C). In 4HT untreated MDCK cells, luciferase activity was strongly increased in response to TGF $\beta$, compared to relatively low basal luciferase activity in the absence of ligand. In MDCK Raf-ER cells pretreated with $4 \mathrm{HT}$, the TGF $\beta$-induced luciferase activity was not changed.

Together, these data indicate that expression of V12Ras or Raf-ER activation in MDCK cells did not prevent the TGF $\beta$-activated Smads from translocating into the nucleus, binding to DNA and activating gene expression.

\section{Raf inhibits apoptosis induced by TNF $\alpha$}

To further investigate whether activation of Raf leads to protection from other pro-apoptotic stimuli than TGF $\beta$, we examined the effect of Raf on TNF $\alpha$-induced apoptosis (Fig. 7). TNF $\alpha$ acts through its death receptor (TNFRI) to cause apoptosis in many epithelial cell types (Sidotide Fraisse et al. 1998). MDCK Raf-ER cells were treated with different concentrations of TNF $\alpha$ for $4 \mathrm{~h}$ in the presence of the protein synthesis inhibitor cycloheximide, which is required to block the anti-apoptotic NF- $\kappa \mathrm{B}$ transcriptional response to TNF $\alpha$. TNF $\alpha$ induced a dose-dependent increase of the percentage of apoptotic cells (Fig. 7A) as well as strong activation of caspase-8 (Fig. 7B), as demonstrated by Hoechst staining or in Western blotting, respectively. In contrast, $4 \mathrm{HT}$ pretreatment protected cells from apoptosis and caused caspase- 8 not to be detectably activated. Moreover, we could show that activation of Raf-ER in MDCK cells blocks detachment-induced apoptosis, "anoikis" (Le Gall et al. 2000; Rytömaa et al. 2000). These results indicate that Raf not only inhibits TGF $\beta$-induced death signaling but renders cells insensitive to a variety of proapoptotic stimuli, suggesting a more general anti-apoptotic function for Raf.

\section{Discussion}

\section{Raf and epithelial-mesenchymal transition}

MDCK cells are an untransformed immortalized dog kidney epithelial line that will form a polarized epithe-
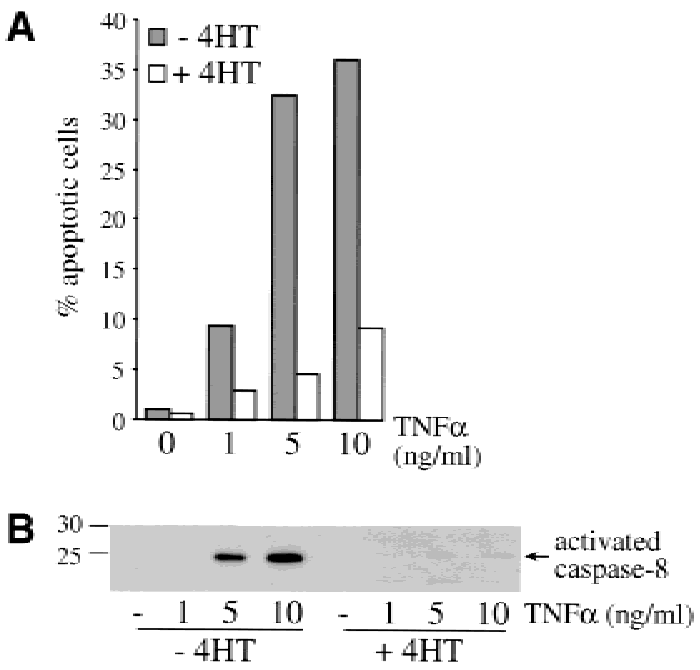

Figure 7. Raf inhibits apoptosis induced by TNF $\alpha$ plus cycloheximide. MDCK Raf-ER cells were either untreated or treated with $100 \mathrm{nM} 4 \mathrm{HT}$ for $24 \mathrm{~h}$ and stimulated with the indicated concentrations of TNF $\alpha$ and cycloheximide $(2 \mu \mathrm{g} / \mathrm{mL})$ for $4 \mathrm{~h}$. (A) The percentage of apoptotic cells was assayed by Hoecht staining. Data shown represent at least three independent experiments performed in duplicates. (B) Activation of caspase- 8 was detected by Western blotting, showing the processed and activated p20 subunit of caspase-8. 
lial monolayer in vitro. We show here that sustained activation of Raf and, consequently, the ERK MAP kinases, using the inducible Raf-ER system is sufficient to cause a change in phenotype from epithelial to mesenchymal. The cells begin to show signs of disassembly of cell-cell contact as early as $8 \mathrm{~h}$ after Raf activation, with tight junctions and adherens junctions breaking up over the first $2 \mathrm{~d}$ of Raf activation. During this time the cells spread and move apart in a scattering response similar to that seen with HGF/SF treatment. The breakup of the cell junctions occurs well before changes in the level of expression of the junction proteins such as E-cadherin and ZO-1 (K. Lehmann and J. Downward, unpubl.); this could involve posttranslational modification of junction proteins or their regulators or a more rapid drop in expression of a particularly labile junction protein not examined here, as has been suggested recently for occludin (Li and Mrsny 2000).

Over the course of a few days following Raf activation the cells begin to produce their own biologically active TGF $\beta$ promoted by the accompanying up-regulation of uPA expression. This autocrine TGF $\beta$ is responsible for promoting the invasive growth of the activated Raf-expressing MDCK cells in collagen gels, as can be demonstrated by the ability of neutralizing antibodies against TGF $\beta$ to block this phenotype in cells where Raf has either been activated for the course of the experiment or for a more prolonged period. There are clear similarities, and some differences, between this system and the previously described activated Ras-transformed EpH4 murine breast epithelial cells, EpRas (Oft et al. 1996). Unlike the cells used here, in the EpRas cells, initial addition of exogenous TGF $\beta$ was required to set up the autocrine TGF $\beta$ loop. However, once established, the autocrine TGF $\beta$ would maintain the invasive phenotype and the EMT, presumably in cooperation with the activated Ras protein.

We previously described an MDCK cell line that constitutively expressed a form of Raf that was activated by localization to the plasma membrane, Raf-CAAX (Khwaja et al. 1997, 1998). Unlike the 4HT-treated RafER MDCK cells, this line did not display a mesenchymal phenotype and did not form invasive growths in collagen gels. It also was not protected from apoptosis in response to detachment from extracellular matrix or other apoptotic insults, again unlike the 4HT-treated Raf-ER MDCK cells. The likely critical difference between these two cell lines is the strength of Raf activity achieved by the two constructs: ERK activation in Raf-ER cells is much higher than the constitutive level in Raf-CAAX cells (data not shown). The strong activity of the Raf-ER construct may also account for why these cells scatter in response to $4 \mathrm{HT}$ while Raf-CAAX expressing cells are not scattered, although they have undergone some morphological changes (Khwaja et al. 1998).

\section{Interplay between Raf and TGF $\beta$ signaling pathways}

It has been suggested that certain tumors lose sensitivity to the inhibitory effects of TGF $\beta$, in particular its ability to cause growth arrest and apoptosis, by losing expression of cell surface receptors for TGF $\beta$. Alternatively, there may be loss of Smad4/DPC4, the critical common Smad that interacts with the TGF $\beta$ receptor-activated Smad2 and Smad3 and translocates with them to the nucleus (Massague 1998). Both of these mechanisms would give rise to a generalized block in TGF $\beta$ signaling. However, it is clear that in many circumstances TGF $\beta$ can promote the malignant phenotype of transformed cells in human tumors or animal cancer models (Akhurst and Balmain 1999), so it is likely that mechanisms exist that allow the tumor cells to avoid the inhibitory effects of TGF $\beta$ while continuing to take advantage of the positive effects.

In the case of the MDCK Raf-ER cells, the change in the response to TGF $\beta$ relative to the parental cells depends on the endpoint studied. Activation of Raf for up to $48 \mathrm{~h}$ before the addition of TGF $\beta$ did not prevent the slowing down of progression through the cell cycle. TGF $\beta$ treatment over $24 \mathrm{~h}$ does not arrest the cells completely, but there is a clear reduction in the rate of proliferation. Interestingly, MDCK Raf-ER cells that have been treated with 4HT for several weeks become completely resistant to the growth inhibitory effects of TGF $\beta$, suggesting that this is a result of the cells having undergone complete EMT and consequent major changes in gene expression profile and not the result of early or intermediate Raf-regulated signaling, either direct or transcriptional. However, the continued dependence of the long-term Raf-transformed cells on the TGF $\beta$ autocrine loop for invasive growth in collagen gels shows that they are still responsive to some of the stimulatory effects of TGF $\beta$.

By contrast, the ability of TGF $\beta$ to induce apoptosis is fairly rapidly blocked by the short-term activation of Raf, well before the onset of EMT, although slowly enough that a transcriptional event could be required. This protection from apoptosis is, however, not specific for TGF $\beta$ and is seen equally clearly for $\mathrm{TNF} \alpha$-induced apoptosis and matrix detachment-induced apoptosis (Le Gall et al. 2000; data not shown). It therefore appears that the short- to medium-term activation of the Raf-ERK pathway inhibits programmed cell death in this system in a nonspecific manner. This, together with the incomplete nature of the inhibition of cell proliferation by TGF $\beta$, allows the cells to largely avoid the inhibitory effects of TGF $\beta$ while responding to it with increased invasiveness characteristic of malignancy and induction of EMT. As EMT is established following longer-term activation of Raf; the inhibitory effects of TGF $\beta$ on cell proliferation are also lost, giving rise to cells that have no antiproliferative/prodeath responses to TGF $\beta$ but do display the pro-invasive responses. At present we do not know the mechanism by which strong Raf activation blocks apoptotic responses in MDCK cells; a similar response seen in another epithelial line, MCF-10A, has been found to be caused by an epidermal growth-factor family autocrine loop resulting in a survival signal (A. Schulze and J. Downward, unpubl.). 


\section{Raf and Smad signaling}

Recently, it has been reported that ERKs can phosphorylate Smad2 and Smad3 in the linker region connecting the MH1 and MH2 domains (Kretzschmar et al. 1999). The ERK phosphorylated Smads cannot translocate to the nucleus in response to TGF $\beta$, leading to a general inhibition of Smad-mediated TGF $\beta$ responses. The fact that clear biological effects of TGF $\beta$ can still be seen in cells following strong and sustained activation of the Raf-ERK pathway suggests the possibility that these effects may be mediated through mechanisms that do not involve Smads. Alternatively, Smad signaling may not be effectively suppressed by active ERK here.

Smad-independent TGF $\beta$ signaling has been reported previously: TGF $\beta$ can activate TAK1, a member of the MAP kinase kinase kinase family, and this activation has been implicated in the rapid activation of p38 MAP kinase by TGFß (Yamaguchi et al. 1995; Hanafusa et al. 1999). In addition, TGF $\beta$ is still able to induce increased expression of fibronectin, although not PAI-1, in tumor cell lines lacking functional Smad4 (Hocevar et al. 1999): This involves a JNK-dependent mechanism. Although it is not known at present whether the invasiveness promoting effects of TGF $\beta$ require JNK or p38 activity, induction of anoikis in MDCK cells does not need these pathways (Khwaja and Downward 1997). Uncertainty as to whether Smad-independent signaling could account for the Raf-resistant effects of TGF $\beta$ led us to revisit the suppression of Smad2 and Smad3 signaling by ERK. Surprisingly, we were unable to see any inhibitory effect of potent Raf activation on the ability of TGF $\beta$ to induce the nuclear translocation of Smad2, Smad3, or Smad4; the DNA binding ability of Smad3 and Smad4; or the transactivation of expression from a reporter construct by Smad2 and Smad4. A lack of effect of expression of activated MEK on nuclear translocation and DNA binding ability of Smad3 has also recently been reported in HaCaT cells (Hu et al. 1999).

At present it is not clear why activation of the RafERK pathway does not block TGF $\beta$ signaling to Smad2 and Smad3 in MDCK cells. It is possible that cell type differences account for this, although we also do not see the effect in EpRas cells, a line used in the study by Kretzschmar et al. (data not shown).

\section{Raf, TGF $\beta$, and cancer}

The data presented here indicate that TGF $\beta$ signaling pathways can synergize with the Ras-Raf-ERK pathway to promote the conversion of normal epithelial cells to highly malignant cells with a mesenchymal phenotype. In MDCK cells, activation of Raf selectively blocks the negative effects but not the positive effects of TGF $\beta$ on cell growth. Inhibition of TGF $\beta$ effects on apoptosis and cell cycle exit are likely to be well downstream of the TGF $\beta$-specific pathways, with Smad-mediated signaling left fully operational. This is in contrast to many reports in the literature of general loss of responsiveness to TGF $\beta$ in some tumor-derived cells. However, there is reason to believe that complete loss of TGF $\beta$ signaling in tumors may be restricted to certain types of cancer and be relatively infrequent overall (Riggins et al. 1997).

TGF $\beta$-receptor type II is mutated in human colon cancer cell lines with high rates of microsatellite instability from families with genetic defects in DNA repair (RER) causing hereditary nonpolyposis colon cancer. In addition, similar mutations are seen in familial gastric cancer from families with RER. Further analysis has found some indication of occasional TGF $\beta$-receptor type II mutation in microsatellite-stable colon carcinoma and of TGF $\beta$ receptor type I in human cervical carcinoma. Overall, the frequency of TGF $\beta$-receptor mutation in human tumors is low. Moreover, it is apparent that some of the mutations found may not block all aspects of TGF $\beta$ receptor signaling. For example, a mutation in TGF $\beta$ receptor type II in a kindred of hereditary nonpolyposis colorectal cancer without microsatellite instability selectively blocks the signaling of TGF $\beta$ to $\mathrm{p} 15^{\mathrm{INK} 4 \mathrm{~B}}$ expression but not to PAI-1 expression (for review, see Kim et al. 2000). Conversely, homozygous mutations in this receptor in two RER positive colorectal cancer cell lines fail to suppress the growth inhibitory response of the cells to TGF $\beta$ (Ilyas et al. 1999).

The other major mechanism for inactivation of TGF $\beta$ signaling in tumors is through loss of function of Smad4, also known as Dpc4 or Madh4. Smad4 inactivation is a common genetic alteration in pancreatic ductal adenocarcinomas. Inactivation of Smad4 occurs in $\sim 50 \%$ of pancreatic cancers; it is relatively rare in other tumor types, although it does occur in a small proportion of cancers from other organs, particularly the colon, and also breast, ovary, and biliary tract (Thiagalingam et al. 1996; Hahn et al. 1998) cancers. Germ-line mutations in the Smad4 gene have also been implicated in juvenile polyposis, (for review, see Weinstein et al. 2000). The relatively small number of tumors in which TGF $\beta$ signaling has been inactivated by mutation of the receptor or Smads might reflect the fact that TGF $\beta$ pathways can act to promote malignancy as well as suppress it. During the process of tumor progression it would be expected that there would be strong selection to lose the growth inhibitory effects of TGF $\beta$ but, also, to maintain the promalignant aspects of the TGF $\beta$ response. This could be achieved by inactivating the growth arrest and apoptosis responses to TGF $\beta$ well downstream of the TGF $\beta$-specific signaling events. Similarly, from the data presented here we propose that the Ras-MAP kinase pathway acts to suppress the inhibitory effects of TGF $\beta$ downstream of Smads, rather than by blanket inhibition of TGF $\beta$ responses.

\section{Material and methods}

Expression vectors

EGFP tagged $\triangle$ Raf-1-hbER (DD) (Raf-ER) cDNA in pBabe-puro was described previously (Woods et al. 1997). Xenopus Fast-1 in pEF-Flag, Xenopus Smad2 in pEF-myc, and pFTX5 pEF-lacZ were described in Howell and Hill (1997). Human Smad3 
(hSmad3) was subcloned into pFTX5. The ARE-Luc construct in pGL3 is equivalent to the ARE-CAT construct previously described (Germain et al. 2000), with luciferase replacing CAT.

\section{Cell culture and retroviral infection}

MDCK cells were cultured in DMEM supplemented with $10 \%$ fetal bovine serum (FBS). Retroviral vector pBabe-puro-EGFP$\Delta$ Raf-1-hbER (DD) was packaged in GP+E cells and used to infect MDCK cells expressing the ecotropic retrovirus receptor. After selection with $2.5 \mu \mathrm{g} / \mathrm{mL}$ of puromycin (Sigma), cells were pooled and Raf-ER-expressing cells were sorted twice by FACS for EGFP expression. MDCK cell lines stably expressing V12Ras have been described previously (Khwaja et al. 1997).

\section{Collagen gel culture}

Cells $\left(3 \times 10^{3}\right)$ were suspended in rat collagen type I (Collaborative Medical Products) and overlaid with DMEM containing 5\% FCS, $5 \mathrm{ng} / \mathrm{mL}$ TGF $\alpha$ (R\&D systems), and $0.04 \mathrm{IE} / \mathrm{mL}$ Insulin (Novo Nordisk). Neutralizing TGF $\beta$ antibodies $(100 \mathrm{ng} / \mathrm{mL}$ chicken anti-TGF $\beta_{1}[R \& D$ systems $]$ and $20 \mu \mathrm{g} / \mathrm{mL}$ mouse anti$\operatorname{TGF}_{1,2,3}[$ Genzyme]) were used. Medium was changed every second day.

\section{Confocal fluorescence microscopy}

Antibodies were from: E-cadherin (Transduction Laboratories); vimentin V3B (Boehringer Mannheim); ZO-1 (Zymed); Cy3-labeled goat antirabbit IgG (Amersham); Cy5-labeled donkey antimouse IgG H+L (Jackson). Rabbit antiserum to cytokeratin has been described previously (Reichmann et al. 1992). Cells grown on $24-\mathrm{mm}$ Falcon cell culture inserts $(0.4 \mu \mathrm{m}$ pore size; Becton Dickinson) were fixed in methanol/acetone (1:1) and immunostained as previously described (Oft et al. 1996). Samples were examined with a Zeiss LSM510 confocal microscope.

\section{Antibodies, Western blotting, and ELISA}

Antibodies were from: ERK2/p42MAPK pan ERK (Transduction Laboratories); estrogen-receptor MC20 (Santa Cruz); TGF $\beta 1$ chicken (R\&D); Urokinase-type Plasminogen Activator Ab-1 (Neo Markers); activated caspase-8 C20, cyclin A H432, Smad4 B8 (Santa Cruz); Smad2 (cross-reacting with Smad3; Transduction Laboratories). The anti-PCNA antibody (PC10) was obtained from the ICRF hybridoma unit. Total cell extracts in SDS-sample buffer and nuclear extracts were prepared as described previously (Wong et al. 1999). Lysates in 1\% Triton $\mathrm{X}-100$ buffer were prepared as described previously (Khwaja et al. 1996). Equal protein amounts of each sample were resolved by SDS-PAGE and transferred onto PVDF membrane (Millipore), and immunoreactive proteins were visualized by ECL (Amersham). Affinity labeling of active caspases was carried out as described in Martins (1997) using 0.5 $\mu \mathrm{M}$ Z-EK(bio)D-aomk peptide (Peptide Institute, Osaka). The TGF $\beta 1$ secretion into cell culture supernatants was determined by ELISA (Promega) according to manufacturer's instructions.

\section{Apoptosis assay}

After trypsinization, cells were fixed in $3.7 \%$ formaldehyde in PBS and for $30 \mathrm{~min}$ at room temperature, stained with $1 \mu \mathrm{g} / \mathrm{mL}$ Hoechst 33258 (Molecular Probes) for $10 \mathrm{~min}$ and examined by fluorescence microscopy following UV illumination. A minimum of 500 cells per sample was scored for apoptotic phenotype.

\section{Cell cycle analysis}

To examine cell cycle distribution, cells were fixed in $70 \%$ ethanol, treated with ribonuclease $(100 \mu \mathrm{g} / \mathrm{mL})$ for $5 \mathrm{~min}$ at room temperature, stained with $50 \mathrm{\mu g} / \mathrm{mL}$ propidium iodide (Becton Dickinson) for $5 \mathrm{~min}$, and analyzed by flow cytometry using 488 nm excitation.

\section{Nuclear extracts and EMSA}

Nuclear extracts were prepared as described previously (Wong et al. 1999). The ${ }^{32} \mathrm{P}$-labeled c-jun oligonucleotide probe was generated by annealing and filling in the overlapping oligonucleotides GGAGGTGCGCGGAGTCAGGCAGACAGACA GACACAGC (sense) and TGCCGACCTGGCTGGCTGGCT GGCTGTGTCTGTCTGTCTG (antisense) by PCR in the presence of $\left[\alpha-{ }^{32} \mathrm{P}\right] \mathrm{dCTP}$ and $\left[\alpha-{ }^{32} \mathrm{P}\right] \mathrm{dATP}$. The EMSA reaction was performed as described previously (Germain et al. 2000) and contained 10-15 $\mu \mathrm{g}$ of nuclear extract. For supershift experiments, the following antibodies and competing peptide were added to the nuclear extracts before probe addition and incubated at room temperature for $5 \mathrm{~min}: 1 \mu \mathrm{L}$ mouse anti-Smad4 (B8; Santa Cruz), $1 \mu \mathrm{L}$ anti-Smad3 without or with $0.5 \mu \mathrm{L}$ competing peptide (Nakao et al. 1997), $0.5 \mu \mathrm{L}$ anti-Smad2 (Transduction Laboratories), or $1 \mu \mathrm{L}$ of anti-Smad2 (SED; Nakao et al. 1997).

\section{Transfection and luciferase assay}

MDCK Raf-ER cells were transiently transfected using Lipofectamine (GIBCO BRL) with ARE-Luc reporter, XFAST-1 expression vector, and lacZ as an internal control for transfection efficiency. Luciferase assays were performed according to the procedures recommended by the supplier (Promega). The $\beta$-galactosidase assays were performed using chlorophenol red- $\beta-D-$ galactopyranoside (Calbiochem) as a substrate and quantified photometrically at $595 \mathrm{~nm}$. All transfections were normalized to $\beta$-galactosidase activity.

\section{Acknowledgments}

We thank M. Serrano, R. Marais, and C. Marshall for supplying reagents used in this study. Thanks also to F. Nicolás, M. Howell, S. Grünert, and M. Martins for helpful discussions.

The publication costs of this article were defrayed in part by payment of page charges. This article must therefore be hereby marked "advertisement" in accordance with 18 USC section 1734 solely to indicate this fact.

\section{References}

Akhurst, R.J. and Balmain, A. 1999. Genetic events and the role of TGF $\beta$ in epithelial tumor progression. J. Pathol. 187: 8290.

Birchmeier, W., Weidner, K.M., and Behrens, J. 1993. Molecular mechanisms leading to loss of differentiation and gain of invasiveness in epithelial cells. J. Cell Sci. (Suppl.) 17: 159164.

Birchmeier, C., Meyer, D., and Riethmacher, D. 1995. Factors controlling growth, motility, and morphogenesis of normal and malignant epithelial cells. Int. Rev. Cytol. 160: 221-266.

Bosch, E., Cherwinski, H., Peterson, D., and McMahon, M. 1997. Mutations of critical amino acids affect the biological and biochemical properties of oncogenic A-Raf and Raf-1. Oncogene 15: 1021-1033. 
Boyer, B., Tucker, G.C., Valles, A.M., Franke, W.W., and Thiery, J.P. 1989. Rearrangements of desmosomal and cytoskeletal proteins during the transition from epithelial to fibroblastoid organization in cultured rat bladder carcinoma cells. J. Cell Biol. 109: 1495-1509.

Boyer, B., Roche, S., Denoyelle, M., and Thiery, J.P. 1997. Src and Ras are involved in separate pathways in epithelial cell scattering. EMBO I. 16: 5904-5913.

Chen, R.H. and Chang, T.Y. 1997. Involvement of caspase family proteases in transforming growth factor- $\beta$-induced apoptosis. Cell Growth Differ. 8: 821-827.

Chen, X., Rubock, M.J., and Whitman, M. 1996. A transcriptional partner for MAD proteins in TGF- $\beta$ signaling. Nature 383: 691-696.

Downward, J. 1998. Ras signaling and apoptosis. Curr. Opin. Genet. Dev. 8: 49-54.

Germain, S., Howell, M., Esslemont, G.M., and Hill, C.S. 2000. Homeodomain and winged-helix transcription factors recruit activated Smads to distinct promoter elements via a common Smad interaction motif. Genes \& Dev. 14: 435451.

Gherardi, E., Gray, J., Stoker, M., Perryman, M., and Furlong, R. 1989. Purification of scatter factor, a fibroblast-derived basic protein that modulates epithelial interactions and movement. Proc. Natl. Acad. Sci. 86: 5844-5848.

Godar, S., Horejsi, V., Weidle, U.H., Binder, B.R., Hansmann, C., and Stockinger, H. 1999. M6P/IGFII-receptor complexes urokinase receptor and plasminogen for activation of transforming growth factor- $\beta 1$. Eur. J. Immunol. 29: 1004-1013.

Greenburg, G. and Hay, E.D. 1986. Cytodifferentiation and tissue phenotype change during transformation of embryonic lens epithelium to mesenchyme-like cells in vitro. Dev. Biol. 115: 363-379.

Hahn, S.A., Bartsch, D., Schroers, A., Galehdari, H., Becker, M., Ramaswamy, A., Schwarte-Waldhoff, I., Maschek, H., and Schmiegel, W. 1998. Mutations of the DPC4/Smad4 gene in biliary tract carcinoma. Cancer Res. 58: 1124-1126.

Hanafusa, H., Ninomiya-Tsuji, J., Masuyama, N., Nishita, M., Fujisawa, J., Shibuya, H., Matsumoto, K., and Nishida, E. 1999. Involvement of the p38 mitogen-activated protein kinase pathway in transforming growth factor- $\beta$-induced gene expression. J. Biol. Chem. 274: 27161-27167.

Hannon, G.J. and Beach, D. 1994. p15INK4B is a potential effector of TGF- $\beta$-induced cell cycle arrest. Nature 371: $257-$ 261.

Hay, E.D. 1995. An overview of epithelio-mesenchymal transformation. Acta Anat. 154: 8-20.

Hocevar, B.A., Brown, T.L., and Howe, P.H. 1999. TGF- $\beta$ induces fibronectin synthesis through a c-Jun N-terminal kinase-dependent, Smad4-independent pathway. EMBO $I$. 18: $1345-1356$.

Howell, M. and Hill, C.S. 1997. XSmad2 directly activates the activin-inducible, dorsal mesoderm gene XFKH1 in Xenopus embryos. EMBO T. 16: 7411-7421.

Hu, P.P., Shen, X., Huang, D., Liu, Y., Counter, C., and Wang, X.F. 1999. The MEK pathway is required for stimulation of p21(WAF1/CIP1) by transforming growth factor- $\beta$. J. Biol. Chem. 274: 35381-35387.

Huang, H.C., Murtaugh, L.C., Vize, P.D., and Whitman, M. 1995. Identification of a potential regulator of early transcriptional responses to mesoderm inducers in the frog embryo. EMBO J. 14: 5965-5973.

Ilyas, M., Efstathiou, J.A., Straub, J., Kim, H.C., and Bodmer, W.F. 1999. Transforming growth factor $\beta$ stimulation of colorectal cancer cell lines: Type II receptor bypass and changes in adhesion molecule expression. Proc. Natl. Acad.
Sci. 96: 3087-3091.

Khwaja, A. and Downward, J. 1997. Lack of correlation between activation of Jun-NH2-terminal kinase and induction of apoptosis after detachment of epithelial cells. J. Cell Biol. 139: $1017-1023$.

Khwaja, A., Hallberg, B., Warne, P.H., and Downward, J. 1996. Networks of interaction of p120cbl and p130cas with Crk and Grb2 adaptor proteins. Oncogene 12: 2491-2498.

Khwaja, A., Rodriguez-Viciana, P., Wennstrom, S., Warne, P.H., and Downward, J. 1997. Matrix adhesion and Ras transformation both activate a phosphoinositide $3-\mathrm{OH}$ kinase and protein kinase B/Akt cellular survival pathway. EMBO I. 16: 2783-2793.

Khwaja, A., Lehmann, K., Marte, B.M., and Downward, J. 1998. Phosphoinositide 3-kinase induces scattering and tubulogenesis in epithelial cells through a novel pathway. J. Biol. Chem. 273: 18793-18801.

Kim S.-J., Im, Y.-H., Markowitz, S.D., and Bang, Y.-J. 2000. Molecular mechanisms of inactivation of TGF- $\beta$ receptors during carcinogenesis. Cytokine Growth Factor Rev. 11: 159168.

Kretzschmar, M., Doody, J., Timokhina, I., and Massague, J. 1999. A mechanism of repression of TGF $\beta /$ Smad signaling by oncogenic Ras. Genes \& Dev. 13: 804-816.

Le Gall, M., Chambard, J.C., Breittmayer, J.P., Grall, D., Pouyssegur, J., and Van Obberghen-Schilling, E. 2000. The p42/p44 MAP kinase pathway prevents apoptosis induced by anchorage and serum removal. Mol. Biol. Cell 11: 1103-1112.

Li, D. and Mrsny, R.J. 2000. Oncogenic Raf-1 disrupts epithelial tight junctions via downregulation of occludin. J. Cell Biol. 148: $791-800$.

Lyons, R.M., Gentry, L.E., Purchio, A.F., and Moses, H.L. 1990. Mechanism of activation of latent recombinant transforming growth factor $\beta 1$ by plasmin. J. Cell Biol. 110: 13611367.

Martins, L.M., Kottke, T., Mesner, P.W., Basi, G.S., Sinha, S., Frigon, N., Jr., Tatar, E., Tung, J.S., Bryant, K., Takahashi, A., et al. 1997. Activation of multiple interleukin- $1 \beta$ converting enzyme homologues in cytosol and nuclei of HL-60 cells during etoposide-induced apoptosis. J. Biol. Chem. 272: 7421-7430.

Massague, J. 1998. TGF- $\beta$ signal transduction. Annu. Rev. Biochem. 67: 753-791.

Muzio, M., Chinnaiyan, A.M., Kischkel, F.C., O'Rourke, K., Shevchenko, A., Ni, J., Scaffidi, C., Bretz, J.D., Zhang, M., Gentz, R., et al. 1996. FLICE, a novel FADD-homologous ICE/CED-3-like protease, is recruited to the CD95 (Fas/ APO-1) death-inducing signaling complex. Cell 85: 817-827.

Nakao, A., Imamura, T., Souchelnytskyi, S., Kawabata, M., Ishisaki, A., Oeda, E., Tamaki, K., Hanai, J., Heldin, C.H., Miyazono, K., et al. 1997. TGF- $\beta$ receptor-mediated signaling through Smad2, Smad3 and Smad4. EMBO J. 16: 5353-5362.

Oberhammer, F.A., Pavelka, M., Sharma, S., Tiefenbacher, R., Purchio, A.F., Bursch, W., and Schulte-Hermann, R. 1992. Induction of apoptosis in cultured hepatocytes and in regressing liver by transforming growth factor $\beta 1$. Proc. Nat1. Acad. Sci. 89: 5408-5412.

Oft, M., Peli, J., Rudaz, C., Schwarz, H., Beug, H., and Reichmann, E. 1996. TGF- $\beta 1$ and Ha-Ras collaborate in modulating the phenotypic plasticity and invasiveness of epithelial tumor cells. Genes \& Dev. 10: 2462-2477.

Oft, M., Heider, K.H., and Beug, H. 1998. TGF $\beta$ signaling is necessary for carcinoma cell invasiveness and metastasis. Curr. Biol. 8: 1243-1252.

Ralph, D., McClelland, M., and Welsh, J. 1993. RNA fingerprinting using arbitrarily primed PCR identifies differentially 
regulated RNAs in mink lung $(\mathrm{Mv} 1 \mathrm{Lu})$ cells growth arrested by transforming growth factor $\beta$ 1. Proc. Natl. Acad. Sci. 90: 10710-10714.

Reichmann, E., Schwarz, H., Deiner, E.M., Leitner, I., Eilers, M., Berger, J., Busslinger, M., and Beug, H. 1992. Activation of an inducible c-FosER fusion protein causes loss of epithelial polarity and triggers epithelial-fibroblastoid cell conversion. Cell 71: 1103-1116.

Reynisdottir, I., Polyak, K., Iavarone, A., and Massague, J. 1995. Kip/Cip and Ink4 Cdk inhibitors cooperate to induce cell cycle arrest in response to TGF- $\beta$. Genes \& Dev. 9: 18311845.

Riggins, G.J., Kinzler, K.W., Vogelstein, B., and Thiagalingam, S. 1997. Frequency of Smad gene mutations in human cancers. Cancer Res. 57: 2578-2580.

Roberts, A.B., Anzano, M.A., Lamb, L.C., Smith, J.M., and Sporn, M.B. 1981. New class of transforming growth factors potentiated by epidermal growth factor: Isolation from nonneoplastic tissues. Proc. Nat1. Acad. Sci. 78: 5339-5343.

Rosenthal, E.L., Johnson, T.M., Allen, E.D., Apel, I.J., Punturieri, A., and Weiss, S.J. 1998. Role of the plasminogen activator and matrix metalloproteinase systems in epidermal growth factor- and scatter factor-stimulated invasion of carcinoma cells. Cancer Res. 58: 5221-5230.

Rytömaa, M., Lehmann, K., and Downward, J. 2000. Matrix detachment induces caspase-dependent cytochrome $c$ release from mitrochondria: Inhibition by PKB/Akt but not Raf signalling. Oncogene (in press).

Schoenenberger, C.A., Zuk, A., Kendall, D., and Matlin, K.S. 1991. Multilayering and loss of apical polarity in MDCK cells transformed with viral K-ras. J. Cell Biol. 112: 873-889.

Schulze-Osthoff, K., Ferrari, D., Los, M., Wesselborg, S., and Peter, M.E. 1998. Apoptosis signaling by death receptors. Eur. J. Biochem. 254: 439-459.

Sidoti-de Fraisse, C., Rincheval, V., Risler, Y., Mignotte, B., and Vayssiere, J.L. 1998. TNF- $\alpha$ activates at least two apoptotic signaling cascades. Oncogene 17: 1639-1651.

Stoker, M., Gherardi, E., Perryman, M., and Gray, J. 1987. Scatter factor is a fibroblast-derived modulator of epithelial cell mobility. Nature 327: 239-242.

Thiagalingam, S., Lengauer, C., Leach, F.S., Schutte, M., Hahn, S.A., Overhauser, J., Willson, J.K., Markowitz, S., Hamilton, S.R., Kern, S.E., Kinzler, K.W., and Vogelstein, B. 1996. Evaluation of candidate tumor suppressor genes on chromosome 18 in colorectal cancers. Nat. Genet. 13: 343-346.

Weinstein, M., Yang, X., and Deng, C. 2000. Functions of mammalian Smad genes as revealed by targeted gene disruption in mice. Cytokine Growth Factor Rev. 11: 49-58.

Wolf, B.B. and Green, D.R. 1999. Suicidal tendencies: Apoptotic cell death by caspase family proteinases. I. Biol. Chem. 274: 20049-20052.

Wong, C., Rougier-Chapman, E.M., Frederick, J.P., Datto, M.B., Liberati, N.T., Li, J.M., and Wang, X.F. 1999. Smad3-Smad4 and AP-1 complexes synergize in transcriptional activation of the c-Jun promoter by transforming growth factor $\beta$. Mol. Cell. Biol. 19: 1821-1830.

Woods, D., Parry, D., Cherwinski, H., Bosch, E., Lees, E., and McMahon, M. 1997. Raf-induced proliferation or cell cycle arrest is determined by the level of Raf activity with arrest mediated by p21Cip1. Mol. Cell. Biol. 17: 5598-5611.

Yamaguchi, K., Shirakabe, K., Shibuya, H., Irie, K., Oishi, I., Ueno, N., Taniguchi, T., Nishida, E., and Matsumoto, K. 1995. Identification of a member of the MAPKKK family as a potential mediator of TGF- $\beta$ signal transduction. Science 270: 2008-2011

Yin, J.J., Selander, K., Chirgwin, J.M., Dallas, M., Grubbs, B.G.,
Wieser, R., Massague, J., Mundy, G.R., and Guise, T.A. 1999. TGF- $\beta$ signaling blockade inhibits PTHrP secretion by breast cancer cells and bone metastases development. J. Clin. Invest. 103: 197-206. 


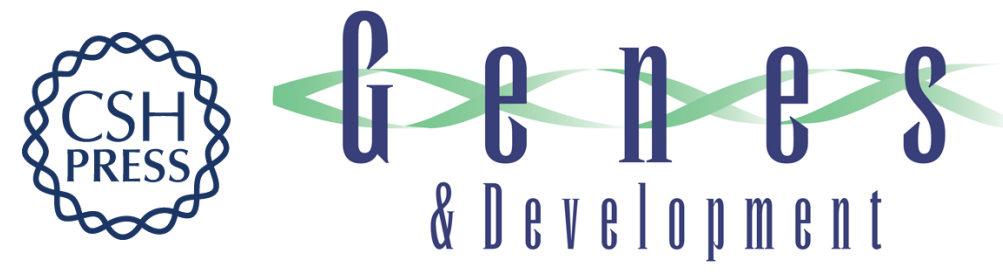

\section{Raf induces TGF $\beta$ production while blocking its apoptotic but not invasive responses: a mechanism leading to increased malignancy in epithelial cells}

Kerstin Lehmann, Elzbieta Janda, Christophe E. Pierreux, et al.

Genes Dev. 2000, 14:

Access the most recent version at doi:10.1101/gad.181700

References This article cites 55 articles, 32 of which can be accessed free at:

http://genesdev.cshlp.org/content/14/20/2610.full.html\#ref-list-1

License

Email Alerting Receive free email alerts when new articles cite this article - sign up in the box at the top

Service right corner of the article or click here.

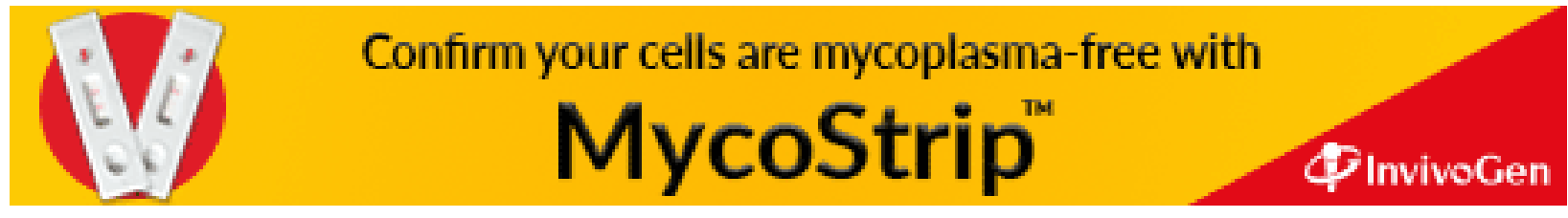

